\author{
B.P. Shipunov, A.V. Ryabykh \\ Altai State University, Barnaul, Russia \\ (E-mail: sbp@mc.asu.ru)
}

\title{
Change in the heat of D-glucose dissolution in water exposed to electromagnetic field
}

\begin{abstract}
The article is devoted to the study of the influence of weak electromagnetic fields of 90,110 and $170 \mathrm{MHz}$ frequency on water properties. The calorimetric measurement of the integral heat of dissolution of non-electrolyte ( $\alpha$-D-glucose) was chosen as an indirect method to study the change in water properties. The heat of $\alpha$-Dglucose dissolution was measured in relation to field frequency for the first time. The results of calorimetric measurements of the thermal effects of the carbohydrate dissolution in field-exposed water compared with unirradiated are presented. The measurements were carried out with a Beckman thermometer. The dependence of the relative heat of $\alpha$-D-glucose dissolution on time after field exposure was established. A cumulative character takes place for the $90 \mathrm{MHz}$ and $110 \mathrm{MHz}$ frequencies. That is reflected in the gradual increase of endoeffect. The dependence has a maximum on the third day in the case of $170 \mathrm{MHz}$. A sharp change in the heat of dissolution was observed within three days for the $90 \mathrm{MHz}$ and $110 \mathrm{MHz}$ frequencies. Further a weak time dependence is registered after twenty days. In general, there is an increase in the endothermicity of the $\alpha$-Dglucose dissolution process. The assumption has been made that the hydration heat of a carbohydrate molecule in field-exposed water reduces due to the increased intermolecular interactions between water particles and weakened interactions between water particles and carbohydrate molecules.
\end{abstract}

Keywords: electromagnetic field, glucose, heat of dissolution, calorimetry, hydration, thermodynamics, carbohydrate solutions, frequency.

\section{Introduction}

Interest in the impact of weak physical fields on different objects is increasing every year. This is primarily due to the fact that the density of such fields of artificial origin grows, covering the region of ever higher frequencies for communication and navigation and increasing the density of broadcasting on the previously used ranges. In this regard, it is interesting to study the problems of efficiency and effectiveness of field impact in various processes. Water and aqueous solutions is one of the common objects of influence. It is known that fields influence the properties of water and aqueous solutions. These effects are explained by a change in the energy of water molecules interaction in a liquid state, i.e. the change in the hydrogen bond energy. Earlier a method to quantify the change in the energy of hydrogen bonds due to the influence of a magnetic field by calorimetric estimation of the heat of solids dissolution was proposed [1].

Internal energy $\mathrm{dU}$ and enthalpy $\mathrm{dH}$ are the thermodynamic functions that describe intermolecular interactions. They are related by the equation $\mathrm{dH}=\mathrm{dU}+\mathrm{pdV}$. The volume change is minimal within solution formation process, therefore the equality of internal energy and enthalpy can be assumed. The enthalpy of dissolution (or the thermal effect of dissolution at constant pressure) can be determined experimentally by the calorimetric method.

Previously, experiments have been conducted to measure the thermal effects of salt dissolution. Starting from the fundamental works of Klassen [2] it was shown that the heat of salts dissolution in magnetized and normal water is noticeably different. In an article [3], it was found that the thermal effect of dissolution for potassium chloride during water magnetization within eight hours changes by $25 \%$. The results on the change in the thermodynamic properties of crystalline hydrates grown from solutions exposed to low-power highfrequency (HF) electromagnetic fields in the range of 30-200 MHz are no less interesting [4]. The presented data shows a multidirectional effect depending on the field frequency. The explanation is based on the assumption of structural reorganization of water and water clusters and changes in the degree of ion hydration, which is also confirmed by experimental data on the measurement of the electrical conductivity of salt solutions in field-affected water [5].

However, a small number of experiments with the dissolution of non-electrolytes in field-exposed water are known to date. Thermal effects of propanol-1 — water mixing are presented in [6]. When using water exposed to a high-frequency electromagnetic field, the heats of mixing noticeably change both towards the 
increase of thermal effect and towards its decrease depending on the field frequency. The changes in the heat of mixing are also dependent on the exposure time and the initial temperature. The authors assume that the observed phenomena occur due to the changes in the energy of interaction of propanol molecules with a structurally reorganized solvent.

In the above studies, we measured either the heat of mixing of two liquids or the heat of dissolution (dehydration) of inorganic salts. To supplement the experimental data, it is of interest to study the dependence of the dissolution enthalpy of a non-electrolyte solid in treated water on the frequency of high-frequency (HF) field.

Natural monosaccharides such as glucose are unique on their properties. Having a chiral atom in its structure and exhibiting optical activity, these molecules are characterized by high hydration capacity due to the presence of a large number of hydroxyl groups. There are other unique properties that ensure the cycle opening in aqueous solution and the conformational transformation of molecules of these carbohydrates [7]. The interest in the thermodynamics of carbohydrates aqueous solutions has not only exhausted, but has increased even more. One of the reasons is the fact that carbohydrate aqueous solutions serve as a good model of solvation interactions [8].

Carbohydrate molecules are bifunctional in relation to their hydration capacity. Hydration includes a specific hydrophilic hydration through the formation of hydrogen bonds between hydroxyl carbohydrate groups and water particles, as well as a specific hydrophobic hydration through intermolecular interactions between $\mathrm{CH}-$ and $\mathrm{CH}_{2}$ - carbohydrate groups and water particles [8].

Application of molecular dynamics methods to aqueous solutions of $\beta$-D-glucose made it possible to model the structure of hydrogen bonds. Calculations showed that the hydrogen-bond network differs little from the network in the crystal structure [9]. It is assumed that when considering the interaction of water with carbohydrate molecules, it is necessary to take into account the complementarity of the geometry of the location of hydroxyl groups and the structural matrix of the solvent [8]. Franks [10,11] first studied the problem of stereospecific hydration of carbohydrates. The specificity of hydration is determined by the ratio of the number of axial and equatorial hydroxyl groups with a preferred hydration of the latter [12]. According to Franks, hydration is ensured by a good agreement between the geometry of the equatorial $\mathrm{OH}$-groups and the water matrix. The distance between the oxygen atoms in equatorial hydroxyls is $0.485 \mathrm{~nm}$, which lies in the region of the second maximum of the radial function of water distribution $(0.49 \mathrm{~nm})$. This fact suggests that the carbohydrate molecule is embedded in the structure of the hydrogen bonds of the solvent [8]. It follows that when glucose dissolves, the dynamic structure of hydrogen bonds is perturbed and recovered, with some water particles being replaced by glucose molecules. In [13] it was assumed that after the dissolution of the carbohydrate the hydrogen-bond network is structured.

Given the above, the research was aimed at the study of changes in the heat of glucose dissolution in water exposed to high-frequency electromagnetic field of certain frequencies.

\section{Experimental}

To estimate the changes in the intermolecular interactions of glucose and field-exposed water, we used the literature data on the integral heats of dissolution. According to these data, the thermodynamic characteristics of $\alpha$-D-glucose dissolution in water at $298.15 \mathrm{~K}$ are as follows:

$\Delta H^{\circ}=11.028 \pm 0.017 \mathrm{~kJ} / \mathrm{mol}$ - integral heat of dissolution at infinite dilution;

$T \Delta S^{0}=18.1 \mathrm{~kJ} / \mathrm{mol}$ - entropy factor;

$\Delta G^{0}=7.1 \pm 0.5 \mathrm{~kJ} / \mathrm{mol}$ — change in Gibbs dissolution energy.

The integral heat of $\alpha$-D-glucose monohydrate dissolution at infinite dilution is $19 \mathrm{~kJ} / \mathrm{mol}[8]$.

The frequencies of the electromagnetic field of 90,110 and $170 \mathrm{MHz}$ were chosen as the most effective, based on previous studies in the field of water systems [15].

The G4-119A high-frequency generator was used to exert a field effect on water. A sample of deionized water was placed in an axial-type cell, the design of which is described in [15]. The cell was connected to a generator, which was used to set a certain frequency of HF field. The field exposure with a certain frequency lasted continuously for two hours. At the end of the field exposure, the water sample was either used immediately or placed in an airtight container and used at different time intervals after the field action. The measurements were carried out on a calorimetric setup, the scheme of which is shown in Figure 1. 


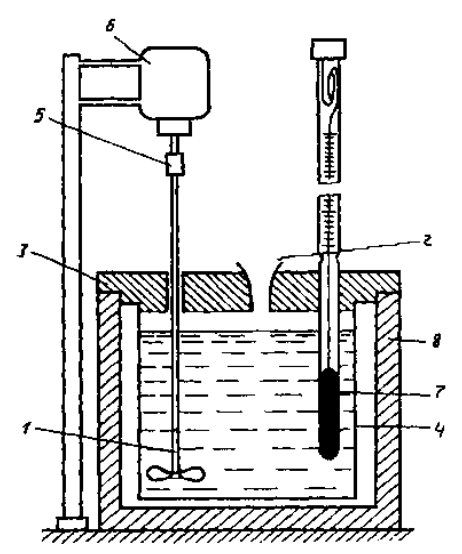

1 - stirrer; 2 - hole for introducing a soluble substance; 3 - lid; 4 - inner coating; 5 - stirrer fixing; 6 - motor; 7 - Beckman thermometer; 8 - outer coating

Figure 1. Scheme of calorimetric setup

For calorimetric measurements, we weighed $2.000 \mathrm{~g}$ of $\alpha$-D-glucose monohydrate accurate to $0.001 \mathrm{~g}$ and placed the sample in a control tube, afterwards the tube was weighed. A pipette was used to measure $100 \mathrm{ml}$ of water, which was poured into a $400 \mathrm{ml}$ porcelain beaker, which was then put into a calorimeter. Thereupon, we placed a tube with glucose and a Beckman metastatic thermometer through a hole 2 . The control tube was kept in a calorimeter until a uniform variation of temperature over time was established. When the range of readings became uniform, we quickly emptied glucose out of the control tube through hole 2 . After the start of the main period, the thermometer readings were recorded every 30 seconds. We completed the measurement when a uniform variation of temperature was established. The control tube was weighed, and the specified mass of dissolved glucose was calculated. The temperature drop corrected for heat exchange was found using the graphical method. A similar experiment was carried out with field-exposed water. Each experiment was repeated twice. The relative change in the dissolution enthalpy was calculated by the formula:

$$
\Delta H_{r}=\frac{\Delta H_{e x}-\Delta H_{C}}{\Delta H_{C}} \cdot 100 \%,
$$

$\Delta \mathrm{H}_{\mathrm{r}}=\frac{\Delta \mathrm{H}_{\mathrm{ex}}-\Delta \mathrm{H}_{\mathrm{c}}}{\Delta \mathrm{H}_{\mathrm{c}}} \cdot 100 \%$,where $\Delta H_{r}$ is the relative change in the heat of dissolution, $\% ; \Delta H_{e x}$ is the heat of dissolution in field-exposed water, $\mathrm{kJ} / \mathrm{mol} ; \Delta H_{c}$ is the heat of dissolution in the control experiment (without field exposure), $\mathrm{kJ} / \mathrm{mol}$.

According to formulas $1-3$, the data were reduced to the same mass of glucose sample:

$$
\frac{\Delta H_{e x} \cdot m_{e x}}{M_{g}}=C \cdot \Delta T_{e x}
$$

By subtracting (1) from (2), dividing the difference by (1) and performing the simplest transformations, we obtained:

$$
\frac{\Delta H_{e x}-\Delta H_{C}}{\Delta H_{C}}=\frac{m_{C} \cdot \Delta T_{e x}-m_{e x} \cdot \Delta T_{C}}{m_{e x} \cdot \Delta T_{C}},
$$

where $m_{c}$ is the mass of glucose in the control experiment; $m_{e x}$ is the mass of glucose in the experiment with field exposure; $C$ is the calorimeter constant, $\mathrm{J} / \mathrm{K} ; \Delta T_{c}$ - temperature change during dissolution in the control experiment $\mathrm{K} ; \Delta T_{e x}$ - temperature change during dissolution in the experiment with field exposure; $M_{g}$ is the molar mass of glucose monohydrate, $\mathrm{g} / \mathrm{mol}$.

Thus, there is no need to determine the calorimeter constant for each experiment, if we compare the heats of dissolution under control.

The heat of glucose dissolution was measured immediately after field action ( 0 days), on days 3,11 , and 21. We also used two water samples subjected to field effect 60 days ago (110 and $170 \mathrm{MHz})$ and 133 days ago (90 MHz).

\section{Results and Discussion}

Obtained dependences of heat of glucose dissolution on time of water exposure $(90,110$ and $170 \mathrm{MHz})$ are presented in Figures $2-4$. 


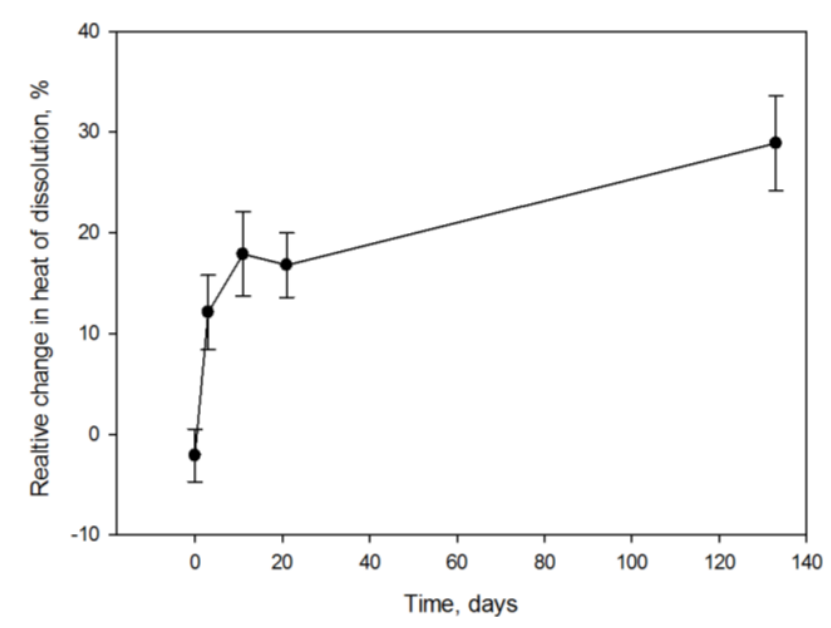

Figure 2. Dependence of heat of glucose dissolution on time of water exposure. Frequency of field exposure $-90 \mathrm{MHz}$

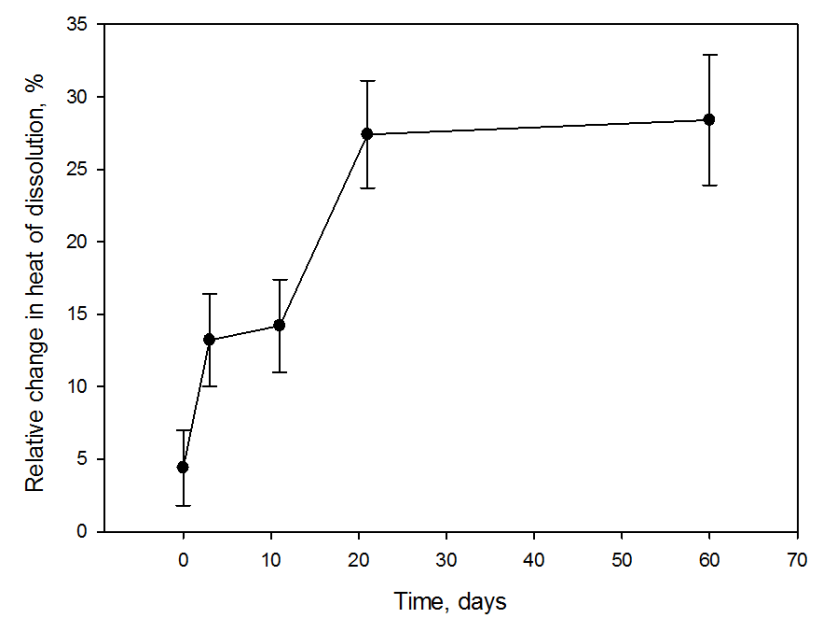

Figure 3. Dependence of heat of glucose dissolution on time of water exposure. Frequency of field exposure $-110 \mathrm{MHz}$

In all cases the dependence of the field effect on the time of water exposure is clearly observed. The heat of dissolution measured immediately after the field effect does not differ from the control one. For each of the frequencies, a sudden change in the heat of dissolution takes place on the third day after the exposure. The time dependence of the effect for the frequencies of $90 \mathrm{MHz}$ and $110 \mathrm{MHz}$ is similar: after the third week a «saturation» of the effect is observed, i.e. it becomes time-independent. For the $170 \mathrm{MHz}$ frequency, there is an extreme dependence; the maximum is reached on the third day. Experimental data correlate with other data given in [14], which reports an increase in field effect during the week.

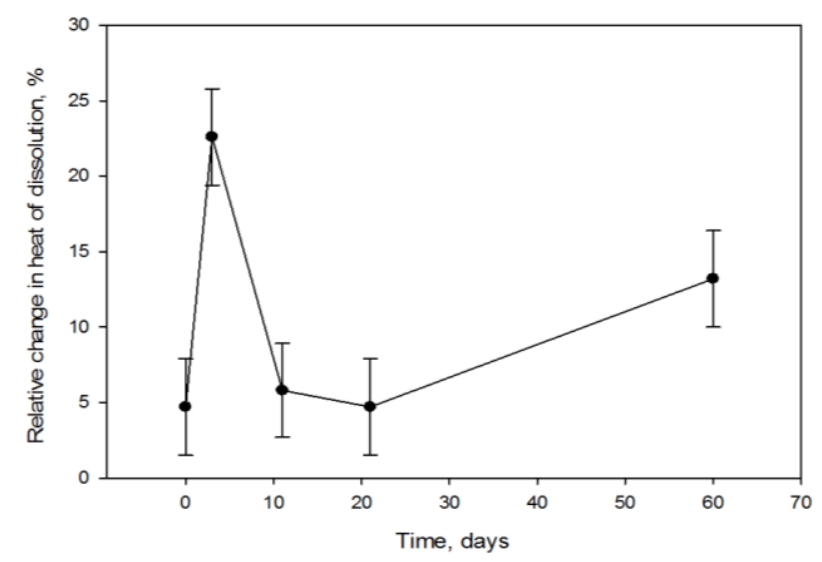

Figure 4 Dependence of heat of glucose dissolution on time of water exposure. Frequency of field exposure $-170 \mathrm{MHz}$ 
The solubility enthalpy can be represented as the sum of two opposite in sign components:

$$
\Delta H_{\text {dissol }}^{0}=\Delta H^{0} \text { cell }+\Delta H_{\text {hydrat }}^{0}
$$

where $\Delta H^{0}$ dissol is the dissolution enthalpy; $\Delta H^{0}$ cell is the enthalpy of the crystal lattice of glucose $(>0) ; \Delta H^{0}$ hydrat is the hydration enthalpy $(<0)$.

As can be seen from the literature data [8], the heat of $\alpha$-D-glucose dissolution is positive. It means that the energy of the crystal lattice prevails over the energy of hydration. The enthalpy of the crystal lattice can be considered constant in all calorimetric experiments, since only water was exposed to the field. Although we used the monohydrate, the heat of hydration cannot be considered equal to zero. An additional intermolecular interaction between water and glucose may occur.

In all cases (except for the first point in Figure 2), a change in the thermal effect towards endothermic values is observed. Based on Franks' assumption that a carbohydrate molecule is embedded in the solvent hydrogen bond network, we can assume an increase in the interactions of homogeneous particles: water water and carbohydrate - carbohydrate. Additional hydration of the monohydrate occurs either to a lesser extent in the field-exposed water, or does not occur at all, or dehydration occurs. This correlates with a change in the heat value in a positive direction, i.e. the predominance of the energy of the crystal lattice over the energy of hydration.

Taking into account the existence of short-lived water molecules associates (clusters), formed by hydrogen bonds, we can assume that the $\mathrm{HF}$ field shifts the equilibrium:

$$
\left(\mathrm{H}_{2} \mathrm{O}\right)_{n} \leftrightarrow \mathrm{H}_{2} \mathrm{O}+\left(\mathrm{H}_{2} \mathrm{O}\right)_{n-1} \leftrightarrow \mathrm{H}_{2} \mathrm{O}+\left(\mathrm{H}_{2} \mathrm{O}\right)_{n-2}
$$

which is characterized by the equilibrium constants $\mathrm{K}_{1}$ and $\mathrm{K}_{2}$.

The values of the constants depend on the strength of interaction of the water molecule with the collective aggregate, which, in turn, essentially depends on the number of particles in the aggregate and the perfection of its structure. If, based on the data of some researchers [16, 17], we consider the energy of separation of water molecule from the $n>10$ aggregate, about $30 \mathrm{~kJ} / \mathrm{mol}$ and take the size of an aggregate of hundreds or thousands of water molecules, then the values of $\mathrm{K}_{1}$ and $\mathrm{K}_{2}$ will differ slightly. Despite the fact that clusters exist for a very short time (a few picoseconds) due to heat motion, they may be formed again. Under this assumption, the time dependence can be explained by the time it takes to reach a new equilibrium between different particles in water. Based on the Figures 2-4, it is possible to conclude that the time to reach equilibrium in the case of frequencies of $90 \mathrm{MHz}$ and $110 \mathrm{MHz}$ is approximately three weeks. At $170 \mathrm{MHz}$ frequency, an unstable equilibrium occurs on the third day, which, for reasons unknown so far, relaxes to the original.

\section{Conclusion}

Summarizing all the above mentioned it is possible to come to the following conclusion:

1. Preliminary field effect on water with frequencies of 90,110 and $170 \mathrm{MHz}$ increases the endothermicity of $\alpha$-D-glucose dissolution;

2. For 90 and $110 \mathrm{MHz}$ frequencies a cumulative time effect is observed, with «saturation» after 21 days. For $170 \mathrm{MHz}$ frequency the maximum effect occurs on the third day;

3. It has been suggested that the interaction of water-water particles increases as a result of the field effect on the solvent that explains the decrease in the enthalpy of carbohydrate hydration;

4. For the first time, it was found that the field effect depends on water exposure time after the field action. The maximum effect for different frequencies is observed under different exposure time.

\section{References}

1 Патент RU 2300757 (C2) Россия. Способ калориметрического определения измерения энергии водородных связей после воздействия на водные системы магнитного поля / Б.П. Шипунов, К.В. Селиков. Опуб. 10.06.2007.

2 Классен В.И. Вода и магнит / В.И. Классен. - М.: Наука, 1973. - 111 с.

3 Селиков К.В. Исследование воздействия постоянного магнитного поля на некоторые свойства воды и водных растворов / К.В. Селиков, Б.П. Шипунов // Изв. вузов. Сер. Химия и хим. технол. -2005 . — Т. 28, № 9. — С. 50-54.

4 Чащевая Ю.В. Влияние ВЧ поля на термодинамическую устойчивость кристаллогидратов хлорида кобальта / Ю.В. Чащевая, Б.П. Шипунов // Изв. вузов. Сер. Физика и химия материалов. - 2014. - Т. 57, № 7/2. — С. $202-204$.

5 Стась И.Е. Влияние высокочастотного электромагнитного поля на свойства растворов хлоридов щелочных металлов / И.Е. Стась, А.П. Гердт, Н.В. Аксенова // Изв. Алтай. гос. ун-та. — 2010. — № 3, 2. - С. 141-145.

6 Стась И.Е. Интегральные молярные теплоты смешения пропанола-1 и воды, подвергшейся воздействию высокочастотного электромагнитного поля / И.Е. Стась, В.Ю. Чиркова // Вестн. ВГУ. Сер. Химия. Биология. Фармация. — 2017. № 2. - C. 36-42. 
7 Кочетков Н.К. Химия углеводов / Н.К. Кочетков, А.Ф. Бочков, А.Б. Дмитриев и др. - М.: Химия, 1966. —672 с.

8 Абросимов В.К. Биологически активные вещества в растворах. Структура. Термодинамика. Реакционная способность / В.К. Абросимов, А.В. Агафонов, Е.В. Антини. - М.: Наука, 2001. - 408 с.

9 Van Eijck B.P. Hydrogen-bond geometry around sugar molecules: Comparison of crystal statistics with simulated aqueous solutions / Van B.P. Eijck, L.M.J. Kroon-Batenburg, J. Kroon // J. Mol. Struct. — 1990. — Vol. 237. — P. 315. $323 \mathrm{p}$.

10 Franks F. Water - a comprehensive treatise / F. Franks, D.S. Reid. — New York, USA: Plenum Press, 1973. — Vol. 2. —

11 Franks F. Physical chemistry of small carbohydrates - equilibrium solution properties // Pure Appl. Chem. — 1982. Vol. 59. - P. 1189.

12 Franks F. Water in food / F. Franks. - M.: Food industry, 1980. - 14 p.

13 Абросимов В.К. Достижения и проблемы теории сольватации. Структурно-термодинамические аспекты / В.К. Абросимов, А.Г. Крестов, Г.А. Альпер. - М., 1998. — 247 с.

14 Шипунов Б.П. Структурная организация и гомогенные равновесия в водных растворах. Влияние электромагнитного поля / Б.П. Шипунов. — Саарбрюкен (Saarbrücken): LAP LAMBERT Academic Publishing, 2014. — 104 c.

15 Stas' I.E. The Stripping Voltammetry // High Frequency Electromagnetic Field / I.E. Stas', B.P. Shipunov, T.S. Ivonina // Electroanalysis. - 2005. - Vol. 17, Iss. 5. - P. 794-799.

16 Lee H.M. Structures, energies, vibrational spectra, and electronic properties, of water monomer to decamer / H.M. Lee, S.B. Suh, J.Y. Lee, P. Tarakeshwar, K.S. Kim // J. Chem. Phys., 2000. — Vol. 112, Iss. 22. — P. 9759-9772.

17 Lee H.M. Structures, energies, and vibrational spectra of water undecamer and dodecamer: an ab initio study / H.M. Lee, S.B. Suh, K.S. Kim // J. Chem. Phys, 2001. — Vol. 114, Iss. 24. — P. 10749-10756.

\title{
Б.П. Шипунов, А.В. Рябых \\ Электромагниттік өріс нәтижесінде суда D-глюкозаның еріген жылу әсерінің өзгеруі
}

Мақала судың қасиеттеріне арналған (90, 110 және 170 МГц) мегартерлердің әлсіз электромагниттік өрістерінің әсерін зерттеуге арналған. Электролит емес, $\alpha$-D-глюкозаны ерітудің интегралдық жылуының калориметриялық өлшемі судың қасиеттерін өзгертудің жанама әдісі ретінде таңдалған. A-D-глюкозаның ерітіндісінің жылуын өлшеу бірінші рет өріс жиілігінің функциясы ретінде өлшенді. Бекманның термометрімен салыстыруға келмеген, өрістегі суда көмірсулардың ерітіндісінің жылу әсерлерін калориметрикалық өлшеу нәтижелері келтірілген. Дала әсерінен кейінгі уақытқа $\alpha$-D-глюкозаны ерітудің салыстырмалы жылу тәуелділігі анықталды. 90 МГц және 110 МГц жиіліктер үшін кумулятивтік сипат бар, ал 170 МГц болған жағдайда тәуелділіктің үшінші күні ең жоғары мәнге ие. 90 МГц және 110 МГц жиіліктер үшін үш күн ішінде еріген жылудың күрт өзгеруі байқалды, содан кейін жиырмасыншы күннен кейін уақытқа тәуелділік аз болады. Жалпы, $\alpha$-D-глюкозаны еріту процесінің эндотермиялықтығы анықталды. Суға әсер ететін судағы көмірсулар молекуласының гидратталуының жылу су бөлшектерінің аралық молекулярлық өзара әрекеттесуі және су бөлшектерімен көмірсулар молекулалары арасындағы өзара әрекеттердің әлсіреуі салдарынан азаяды деп болжануда.

Кілт сөздер: электромагниттік өріс, глюкоза, еріген жылу, калориметрия, ылғалдау, термодинамика, көмірсулардың ерітінділері, жиілігі.

\author{
Б.П. Шипунов, А.В. Рябых
}

\section{Изменение теплового эффекта растворения D-глюкозы в воде в результате действия электромагнитного поля}

Статья посвящена исследованию влияния слабых электромагнитных полей мегагерцового диапазона $(90,110$ и 170 МГц) на свойства воды. В качестве косвенного метода изучения изменения свойств воды было выбрано калориметрическое измерение интегральной теплоты растворения неэлектролита $\alpha$-D-глюкозы. Впервые произведено измерение теплоты растворения $\alpha$-D-глюкозы в зависимости от частоты электромагнитного поля, которое воздействовало на воду. Приведены результаты калориметрических измерений тепловых эффектов растворения углевода в воде, подвергшейся полевому воздействию, по сравнению с необлученной. Измерения проводились с помощью термометра Бекмана. Установлена зависимость относительной теплоты растворения $\alpha$-D-глюкозы от времени после полевого воздействия. Для частот 90 и 110 МГц имеет место накопительный характер, что выражается в постепенном увеличении эндоэффекта, а в случае 170 МГц зависимость возникает максимум на третьи сутки. Для частот 90 и 110 МГц наблюдается резкое изменение теплоты растворения в течение первых трех суток, затем, после двадцатых суток, прослеживается слабая зависимость от времени. В целом, наблюдается увеличение эндотермичности процесса растворения $\alpha$-D-глюкозы в результате полевого 
воздействия на воду. Наблюдаемые эффекты объясняются на основе предположения об уменьшении теплоты гидратации молекулы углевода в воде, подвергшейся полевому воздействию, вследствие усиления межмолекулярных взаимодействий между частицами воды и ослабления взаимодействий между частицами воды и молекулами углевода.

Ключевые слова: электромагнитное поле, глюкоза, теплота растворения, калориметрия, гидратация, термодинамика, растворы углеводов, частота.

\section{References}

1 Shipunov, B.P. \& Selikov, K.V. (2007). Sposob kalorimetricheskoho opredeleniia izmereniia enerhii vodorodnykh sviazei posle vozdeistviia na vodnye sistemy mahnitnoho polia [Method for calorimetric determination of measuring hydrogen bond energy after exposure to aqueous magnetic field systems]. Russian Patetnt No. RU 2300757 (C2). Publ. 10.06.2007 [in Russian].

2 Klassen, V.I. (1973). Voda i mahnit [Water and magnet]. Moscow: Nauka [in Russian].

3 Selikov, K.V. \& Shipunov, B.P. (2005). Issledovanie vliianiia postoiannoho mahnitnoho polia na nekotorye svoistva vody i vodnykh rastvorov [Investigation of the effect of a constant magnetic field on some properties of water and aqueous solutions]. Izvestiia vuzov. Seriia Khimiia i khimicheskaia tekhnolohiia - Russian journal of chemistry and chemical technology, 28, 9, 50-54 [in Russian].

4 Chashevaya, Yu.V. \& Shipunov, B.P. (2014). Vliianie vysokochastotnykh polei na termodinamicheskuiu stabilnost kristallohidratov khlorida kobalta [The effect of high-frequency fields on the thermodynamic stability of cobalt chloride crystal hydrates]. Izvestiia vuzov. Seriia fizika i khimiia materialov - Russian journal of physics, 57, 7/2, 202-204 [in Russian].

5 Stas', I.E., Gerdt, A.P. \& Aksenova, N.V. (2010). Vliianie vysokochastotnoho elektromahnitnoho polia na svoistva rastvorov khloridov shchelochnykh metallov [Effect of high-frequency electromagnetic field on the properties of alkali metal chloride solutions]. Izvestiia Altaiskoho hosudarstvennoho universiteta — Izvestiia of Altai State University Journal, 3-2, 141-145 [in Russian].

6 Stas', I.E. \& Chirkova, V.U. (2017). Intehralnaia moliarnaia teplota smesi propanola-1 i vody pod vozdeistviiem vysokochastotnoho elektromahnitnoho polia [Integral molary heat of mixture of propanol-1 and water, exposed to high-frequency electromagnetic field]. Vestnik Voronezhskoho hosudarstvennoho universiteta. Seriia Khimiia. Biolohiia. Farmatsiia — Proceeding of Voronezh State University. Series Chemistry. Biology. Pharmacy, 2, 36-42 [in Russian].

7 Kochetkov, N.K., Bochkov, A.F. \& Dmitriev, A.B. (1966). Khimiia uhlevodov [Chemistry of carbohydrates]. Moscow: Khimiia [in Russian].

8 Abrosimov, V.K. (2001). Biolohicheski aktivnye veshchestva v rastvore. Struktura. Termodinamika. Reaktivnost [Biologically active substances in solution. Structure. Thermodynamics. Reactivity]. Moscow: Nauka [in Russian].

9 Van Eijck, B.P., Kroon-Batenburg, L.M.J. \& Kroon, J. (1990). Hydrogen-bond geometry around sugar molecules: Comparison of crystal statistics with simulated aqueous solutions. J. Mol. Struct., 237, 315.

10 Franks, F., Reid, D.S. (1973). Water - a comprehensive treatise (Vol. 2). New York: Plenum Press.

11 Franks, F. (1989). Physical chemistry of small carbohydrates - equilibrium solution properties. Pure Appl. Chem., $59,1189$.

12 Franks, F. (1980). Water in food. Moscow: Food industry.

13 Abrosimov, V.K., Krestov A.G. \& Alper G.A. (1998). Dostizheniia i problemy teorii solvatatsii: strukturnyi i termodinamicheskii aspekty [Achievements and problems of the theory of solvation: Structural and thermodynamic aspects]. Moscow: Nauka [in Russian].

14 Shipunov, B.P. (2014). Strukturnaia orhanizatsiia i homohennoe ravnovesie v vodnykh rastvorakh. Vliianie polevoho vozdeistviia [Structural organization and homogeneous equilibrium in aqueous solutions. The influence of the electromagnetic field]. Saarbrücken: LAP Lambert Academic Publishing [in Russian].

15 Stas', I.E., Shipunov, B.P. \& Ivonina, T.S. (2005). The Stripping Voltammetry in High Frequency Electromagnetic Field. Electroanalysis, 17, 5, 794-799.

16 Lee, H.M., Suh, S.B., Lee, J.Y., Tarakeshwar, P. \& Kim, K.S. (2000). Structures, energies, vibrational spectra, and electronic properties, of water monomer to decamer. Journal of Chemical Physics, 112, 22, 9759-9772.

17 Lee, H.M., Suh, S.B. \& Kim, K.S. (2001). Structures, energies, and vibrational spectra of water undecamer and dodecamer: an ab initio study. Journal of Chemical Physics, 114, 24, 10749-10756. 